\title{
Unusual case of acute onset abdominal pain: uses and limitations of medical imaging
}

\author{
Glen Bandiera, MD, MEd;* Eric Poulin, $\mathrm{MD}^{\dagger}$
}

\begin{abstract}
A 28-year-old male with atraumatic abdominal pain and transient hypotension was assessed using bedside emergency department (ED) ultrasonography and contrast enhanced helical computed tomography (CT). Both tests revealed free intraperitoneal fluid, but neither detected a splenic defect. The patient subsequently underwent splenectomy for a ruptured spleen. His serology for typical viral causes was negative. This article discusses spontaneous splenic rupture, the role of imaging in diagnosis, and the limitations of ED ultrasound and contrast enhanced helical CT.
\end{abstract}

Key words: abdominal pain, spleen rupture, ultrasound, emergency department, Epstein-Barr

\section{RÉSUMÉ}

Un homme âgé de 28 ans souffrant d'une douleur abdominale traumatique et d'hypotension transitoire subit à son chevet au département d'urgence une échographie et une tomodensitométrie hélicoïdale (TDM) avec injection d'un agent de contraste. Les deux épreuves révélèrent la présence de liquide libre intrapéritonéal, mais ni l'une ni l'autre des techniques ne décela d'anomalie au niveau de la rate. Le patient subit ensuite une splénectomie pour rupture de la rate. Son bilan sérologique pour des causes virales typiques était négatif. Le présent article discute de la rupture spontanée de la rate, du rôle de l'imagerie dans le cadre du diagnostic et des limites de l'échographie et de la TDM hélicoïdale avec injection d'un agent de contraste au département d'urgence.

\section{Introduction}

Patients frequently present to the emergency department (ED) with abdominal pain. Although many cases of abdominal pain are non-specific and defy timely diagnosis, emergency physicians must rapidly recognize all potentially lifethreatening conditions. ${ }^{1,2}$ In recent years, medical imaging modalities such as bedside ED ultrasonography and contrast enhanced helical computed tomography (CT) have assumed a larger role in the ED diagnosis of abdominal pain..$^{3-5}$ Although these modalities often provide valuable information, it is important to recognize their limitations. The following case illustrates an uncommon but important cause of abdominal pain and highlights the limitations of ED ultrasonography and contrast enhanced helical CT.

\section{Case report}

A 28-year-old male presented to an urban ED one hour after the onset of central abdominal pain. The pain began

\footnotetext{
*Staff Emergency Physician, Trauma Team Leader, St. Michael's Hospital, Toronto, Ont., and Assistant Professor, Clinician Educator, Division of Emergency Medicine, Department of Medicine, University of Toronto, Toronto, Ont.

+Surgeon-in-Chief, St. Michael's Hospital, Toronto, and Associate Professor, Department of Surgery, University of Toronto

Received: Apr. 11, 2003; final submission: May 12, 2003; accepted: May 12, 2003

This article has been peer reviewed.

Can J Emerg Med 2003;5(4):263-7
} 
abruptly while he was putting on hockey equipment, and was associated with a single episode of vomiting. He denied trauma and had not yet begun to play hockey. He had recently experienced episodes of fatigue and dizziness, which had been diagnosed as an ear infection and treated with amoxicillin. He denied fever, recent abdominal symptoms, or significant past medical history apart from a remote episode of pneumonia.

His vital signs included a temperature of $36.2{ }^{\circ} \mathrm{C}$, respiratory rate of 16 breaths/min, oxygen saturation of $99 \%$ on room air, blood pressures of $115 / 72 \mathrm{~mm} \mathrm{Hg}$ lying and 100/69 mm Hg sitting, and a pulse of 100 beats/min lying and 110 beats/min sitting. His chest examination was normal, but he had tenderness in the epigastrium and left upper quadrant without guarding, rebound or shake tenderness. He had a vague fullness in his left upper quadrant, with no frank masses. Rectal examination was normal and negative for occult blood.

Two large bore IVs were started, a 1-litre bolus of normal saline was given, and blood was crossmatched. Results of bedside ED ultrasonography revealed fluid in Morrison's pouch (Fig. 1) and in the splenorenal recess. His initial blood cell results (all given as $\times 10^{9} / \mathrm{L}$ with normal values in parentheses) were as follows: white blood cells = 10.35 (4-11), polymorphonuclear lymphocytes $=0.62$ $(2.0-6.3)$, lymphocytes $=7.97(1.0-3.2)$, eosinophils $=$ $0.10(0.04-0.4)$, basophils $=0.10(0-0.1)$, metamyelocytes $0.10(0)$ and atypical lymphocytes $1.45(0)$. Other results included a hemoglobin level of 114 (130-170) g/L, hematocrit of $0.33(0.39-0.49)$, and a platelet count of 210 $(150-450) \times 10^{9} / \mathrm{L}$. Serum electrolyte levels (in $\mathrm{mmol} / \mathrm{L}$ ) were as follows: sodium 134 (135-145), potassium 4.6 (3.5-5), chloride 98 (96-106), and carbon dioxide 30 (22-30). The anion gap was $6(8-16) \mathrm{mmol} / \mathrm{L}$, urea nitrogen was $2.1(4-6) \mathrm{mmol} / \mathrm{L}$ urea and creatinine was 71 (60-120) $\mu \mathrm{mol} / \mathrm{L}$.

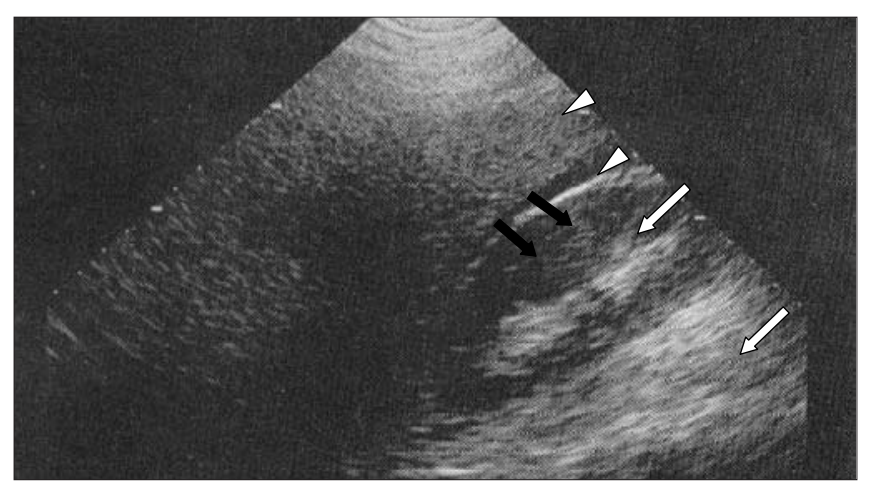

Fig. 1. Bedside ultrasound of Morrison's pouch demonstrating free fluid (black arrows) between the kidney (white arrows)) and liver (arrowheads).
The patient's vital signs improved after the initial fluid challenge, and a surgical consult was obtained. The surgical resident and emergency physician felt the patient was stable enough to undergo a contrast enhanced helical CT, which revealed a moderately enlarged spleen, free fluid in the abdomen and no focal hollow viscus or solid organ abnormality (Fig. 2). In view of the enlarged spleen and atypical lymphocytosis, a monospot was ordered.

Because no bleeding source was apparent, the patient was admitted to the general surgery service for close observation, including hourly vital signs, serial abdominal examinations and blood work every 4 hours. Over a period of hours the abdominal findings increased, and the hemoglobin fell to $84 \mathrm{~g} / \mathrm{L}$. At noon the following day, approximately 16 hours after presentation, the patient became hypotensive, and 2 units of packed red cells were transfused. He then underwent exploratory laparoscopy, laparotomy and total splenectomy for a ruptured spleen. At surgery, the spleen was large and spongy. A subsequent pathology report suggested mononucleosis, but serology was negative for Epstein-Barr virus on 2 occasions and negative for toxoplasmosis, HIV and cytomegalovirus (IgM and $\operatorname{IgG}$ ). The patient was given a pneumococcus vaccination, discharged on postoperative day 10 and made an uneventful recovery.

\section{Discussion}

This case of spontaneous splenic rupture highlights $3 \mathrm{im}-$ portant principles: an approach to abdominal pain and hypotension, the consideration of spontaneous splenic rupture, and imaging modalities for acute abdominal pathology.

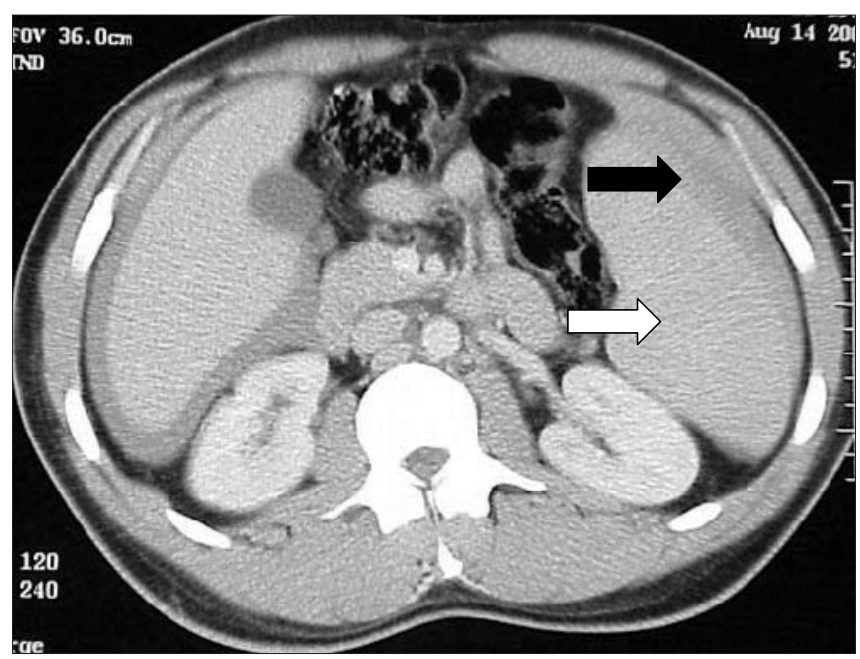

Fig. 2. Contrast enhanced helical CT of abdomen showing free fluid (black arrows) around the liver and enlarged, but otherwise normal, spleen (white arrow). 
The approach to a patient demonstrating signs of hemodynamic compromise and abdominal pain is generic. This patient had a resting tachycardia and postural vital signs that suggested volume depletion. Initial management includes large-bore reliable IV access, fluid administration, preparation for blood transfusion, surgical consultation, careful monitoring and a search for blood loss, which may involve diagnostic imaging. ${ }^{4} \mathrm{~A}$ definitive diagnosis is not required for these interventions. Physical examination of the abdomen can be misleading because acute hemoperitoneum may not cause signs of peritonitis in the early stages. ${ }^{6,7}$ Objective evidence of blood loss as the cause of atraumatic shock should therefore be sought if possible.

\section{Spontaneous splenic rupture}

The diagnosis of spontaneous splenic rupture should be entertained in young patients with acute atraumatic abdominal pain who have symptoms suggesting a recent viral syndrome. ${ }^{89}$ Spontaneous splenic rupture from infectious causes has been described most often in association with Epstein-Barr virus (EBV), cytomegalovirus, toxoplasmosis and acute HIV infection. Other causes include lymphoma and lymphoproliferative diseases, solid neoplasms, aneurysm, pancreatitis, dengue fever, Q fever, typhoid fever and malaria. ${ }^{10-15}$ Although EBV is the most common predisposing factor to spontaneous splenic rupture, this complication occurs in less than $0.5 \%$ of cases of EBV infection. ${ }^{16}$ The peak time for rupture is in the third week of illness. Although most patients give a clear history of antecedent viral syndrome, some present with splenic rupture as the initial event. ${ }^{17} \mathrm{Up}$ to $10 \%$ of adults exhibit a negative monospot (anti-heterophilic antibody) test in spite of acute EBV infection. ${ }^{18}$ Our patient had negative tests for all of these infections (including repeat EBV serology), but did have a positive antiviral capsid antigen test, indicating an EBV exposure of uncertain timing. Based on the spleen pathology report, antecedent malaise, and atypical lymphocytosis, the final (most likely) diagnosis in this case was mononucleosis syndrome.

Conservative (non-operative) therapy is widely accepted for patients with traumatic splenic rupture who are stable, but the literature is less clear in cases of spontaneous rupture, where most surgeons still advocate splenectomy. Reports of conservative therapy are becoming more common; ${ }^{19-21}$ therefore, a trial of conservative management was attempted in our patient. Again, it should be emphasized that in an unstable patient, the decision to proceed to the operating room should be based on clinical suspicion of active hemorrhage and, if available and appropriate, demonstration of free fluid on ultrasound. Had our patient demonstrated ongoing hemodynamic instability, immediate laparoscopy/laparotomy without the need for imaging may have been warranted. Indeed, that is what happened the following morning when his vital signs deteriorated.

\section{Imaging}

Bedside ED ultrasound does not provide a comprehensive evaluation of the abdomen; rather, it offers simple Yes or No answers to specific questions..$^{22}$ The common indications for ED ultrasonography include determining the presence or absence of the following: gallstones, abdominal aortic aneurysm, intrauterine gestation, pericardial fluid and intraperitoneal fluid, and hydronephrosis related to urolithiasis. ${ }^{23-29}$ Bedside ED ultrasound is also used to identify ocular and soft tissue foreign bodies, locate veins for vascular access and to assess cardiac function. ${ }^{30-33}$ Comprehensive overviews of ultrasound capabilities in emergency medicine can be found elsewhere. ${ }^{34-39}$

Focused abdominal sonography looking for free intraperitoneal fluid is easily learned and mastered in the trauma setting. ${ }^{25,40}$ It is a rapid test, ${ }^{4,41}$ it does not require transporting the patient out of the $\mathrm{ED},{ }^{29}$ and it can be repeated serially to monitor changes and support difficult management decisions, such as justifying transfer of a stable patient to another facility or to an intensive care setting. In emergency physicians' hands, rapid trauma ultrasound for intraperitoneal fluid has up to $90 \%$ sensitivity, $99 \%$ specificity and $96 \%$ negative predictive value. ${ }^{25,29,42}$ Because all kinds of fluid look similar on ultrasound, and fluid distribution patterns within the peritoneal cavity are predictable, many programs use peritoneal dialysis patients or patients with ascites for training purposes. Thus, there is reason to believe that the techniques and interpretations for traumatic and atraumatic abdominal fluid are transferable. However, emergency physicians should recognize that ED ultrasonography cannot identify the source and type of fluid, may not detect volumes of less than $200 \mathrm{cc}$ to $500 \mathrm{cc}$ of fluid (depending on operator expertise), and does not detect retroperitoneal fluid., ${ }^{4,434}$ As with other diagnostic tests and physical findings, ED ultrasonography results must be interpreted in light of pretest probability. In situations where a strong clinical suspicion of a condition exists, clinicians should not rely on a negative ultrasound to rule out the condition.

In the patient described, bedside ED ultrasonography narrowed the initial differential diagnosis and prompted the use of contrast enhanced helical CT to clarify the source and severity of potential bleeding, and delineate options for conservative care. Had ultrasound not been available and the patient remained stable, further imaging may 
have been delayed until the morning. Conversely, had the patient deteriorated, an urgent CT may not have then been safe, and urgent exploratory laparotomy would have been indicated.

Contrast enhanced helical CT is useful in the diagnosis of many acute abdominal conditions, including ischemic bowel, inflammatory bowel disease, intestinal obstruction, diverticulitis, appendicitis, pancreatitis, vascular catastrophes and renal stones. ${ }^{45-53}$ It is most cost-effective when used to answer focused questions that define the need for specific interventions, but its utility in undifferentiated abdominal pain remains unclear. ${ }^{3}$ Contrast enhanced helical CT is approximately $95 \%$ sensitive for splenic injury and, in many cases, CT will define the nature and severity of parenchymal organ injuries. ${ }^{43}$ In our patient, it definitively identified intraperitoneal fluid that had a density compatible with blood, but it failed to identify the source of bleeding. Problems with CT scanning include the need to move the patient out of an acute care area, the time required to complete the test, higher cost, limited availability, and poor sensitivity for hollow viscus injuries and bowel perforation.

\section{Conclusions}

Spontaneous rupture of the spleen is an uncommon but important cause of acute atraumatic abdominal pain. Bedside ED ultrasonography is a rapid and sensitive test for acute hemoperitoneum, but rarely defines the source of bleeding. Contrast enhanced helical CT can help determine the feasibility of conservative therapy but may not be appropriate for unstable patients, and a negative scan does not obviate the need for close observation. Finally, with an unstable patient and a suspicion of intraperitoneal bleeding, the decision to operate is primarily clinical and should not be delayed while definitive investigations are completed.

Competing interests: None declared.

\section{References}

1. Jess P, Bjerregaard B, Brynitz S, Holst-Christensen J, Kalaja E, Lund-Kristensen J, et al. Prognosis of acute nonspecific abdominal pain. A prospective study. Am J Surg 1982;144(3):338-40.

2. Lukens TW, Emerman C, Effron D. The natural history and clinical findings in undifferentiated abdominal pain. Ann Emerg Med 1993;22(4):690-6.

3. Gore RM, Miller FH, Pereles FS, Yaghmai V, Berlin JW. Helical CT in the evaluation of the acute abdomen. AJR Am J Roentgenol 2000;174(4):901-13.

4. King KE, Wightman J. Abdominal Pain. In: Marx J, editor. Rosen's emergency medicine. 5 ed, vol 1. St. Louis: Mosby; 2002. p. 185-94.

5. Klinkert P, Kluit AB, de Vries AC, Puylaert JB. Spontaneous rupture of the spleen: role of ultrasound in diagnosis, treatment, and monitoring. Eur J Surg 1999;165(7):712-3.

6. Marx J. Abdominal trauma. In: JA Marx, editor. Emergency medicine: concepts and clinical practice. Vol 1. Philadelphia: Mosby-Year Book; 2002. p. 415-36.

7. Rodriguez A, DuPriest RW Jr, Shatney CH. Recognition of intra-abdominal injury in blunt trauma victims. A prospective study comparing physical examination with peritoneal lavage. Am Surg 1982;48(9):457-9.

8. Hoagland RJ, Henson HM. Splenic rupture in infectious mononucleosis. Ann Intern Med 1957;46:1184-91.

9. Rothwell S, McAuley D. Spontaneous splenic rupture in infectious mononucleosis. Emerg Med (Fremantle) 2001;13(3):364-6.

10. Torricelli P, Coriani C, Marchetti M, Rossi A, Manenti A. Spontaneous rupture of the spleen: report of two cases. Abdom Imaging 2001;26(3):290-3.

11. Gupta R, Singh G, Bose SM, Vaiphei K, Radotra B. Spontaneous rupture of the amyloid spleen: a report of two cases. J Clin Gastroenterol 1998;26(2):161.

12. N'Guyen Cat R, Leynaud G, Martin J, Dufour J, Assadourian R. Spontaneous rupture of the spleen during chronic pancreatitis. A report on two new cases [Author translation]. Sem Hop 1980;56 (11-12):575-8.

13. Windham TC, Risin SA, Tamm EP. Spontaneous rupture of a nontraumatic intrasplenic aneurysm. N Engl J Med 2000;342 (26):1999-2000.

14. Sugahara K, Togashi H, Aoki M, Mitsuhashi H, Matsuo T, Watanabe $\mathrm{H}$, et al. Spontaneous splenic rupture in a patient with large hepatocellular carcinoma. Am J Gastroenterol 1999;94(1): 276-8.

15. Redondo MC, Rios A, Cohen R, Ayala J, Martinez J, Arellano $\mathrm{G}$, et al. Hemorrhagic dengue with spontaneous splenic rupture: case report and review. Clin Infect Dis 1997;25(5):1262-3.

16. Asgari MM, Begos DG. Spontaneous splenic rupture in infectious mononucleosis: a review. Yale J Biol Med 1997;70(2):175-82.

17. $\mathrm{Ra} \mathrm{B}$. Spontaneous rupture of the spleen as presenting event in infectious mononucleosis. Scand J Infect Dis 2001;33(11):872-4.

18. Polis MA, Tenagne H. Viruses. In: Marx JA, editor. Emergency medicine: concepts and clinical practice. Vol 2. Philadelphia: Mosby-Year Book; 2002. p. 1812-34.

19. Peters RM, Gordon LA. Nonsurgical treatment of splenic hemorrhage in an adult with infectious mononucleosis. Case report and review. Am J Med 1986;80(1):123-5.

20. McLean ER Jr, Diehl W, Edoga JK, Widmann WD. Failure of conservative management of splenic rupture in a patient with mononucleosis. J Pediatr Surg 1987;22(11):1034-5.

21. Schwarz M, Zaidenstein L, Freud E, Neuman M, Ziv N, Kornreich L, et al. Spontaneous splenic rupture in infectious mononucleosis: conservative management with gradual percutaneous drainage of a subcapsular hematoma. Pediatr Surg Int 1999;15 (2):139-40

22. Schlager D, Lazzareschi G, Whitten D, Sanders AB. A prospective study of ultrasonography in the ED by emergency physicians. Am J Emerg Med 1994;12(2):185-9.

23. Kendall JL, Shimp RJ. Performance and interpretation of focused right upper quadrant ultrasound by emergency physicians. J Emerg Med 2001;21(1):7-13.

24. Kuhn M, Bonnin RL, Davey MJ, Rowland JL, Langlois SL. Emergency department ultrasound scanning for abdominal aortic aneurysm: accessible, accurate, and advantageous. Ann Emerg Med 2000;36(3):219-23.

25. Mandavia DP, Aragona J, Chan L, Chan D, Henderson SO. Ultrasound training for emergency physicians - a prospective study. Acad Emerg Med 2000;7(9):1008-14.

26. Mateer J, Plummer D, Heller M, Olson D, Jehle D, Overton D, 
et al. Model curriculum for physician training in emergency ultrasonography. Ann Emerg Med 1994;23(1):95-102.

27. Morse JW, Saracino BS, Melanson SW, Arcona S, Heller MB. Ultrasound interpretation of hydronephrosis is improved by a brief educational intervention. Am J Emerg Med 2000;18(2): 186-8.

28. Shih $\mathrm{CH}$. Effect of emergency physician-performed pelvic sonography on length of stay in the emergency department. Ann Emerg Med 1997;29(3):348-51; discussion, 352.

29. Boulanger BR, McLellan BA, Brenneman FD, Wherrett L, Rizoli SB, Culhane J, et al. Emergent abdominal sonography as a screening test in a new diagnostic algorithm for blunt trauma. J Trauma 1996;40(6):867-74.

30. Blaivas M, Theodoro D, Sierzenski PR. A study of bedside ocular ultrasonography in the emergency department. Acad Emerg Med 2002;9(8):791-9.

31. Miller AH, Roth BA, Mills TJ, Woody JR, Longmoor CE, Foster B. Ultrasound guidance versus the landmark technique for the placement of central venous catheters in the emergency department. Acad Emerg Med 2002;9(8):800-5.

32. Moore CL, Rose GA, Tayal VS, Sullivan DM, Arrowood JA, Kline JA. Determination of left ventricular function by emergency physician echocardiography of hypotensive patients. Acad Emerg Med 2002;9(3):186-93.

33. Orlinsky M, Knittel P, Feit T, Chan L, Mandavia D. The comparative accuracy of radiolucent foreign body detection using ultrasonography. Am J Emerg Med 2000;18(4):401-3.

34. Hauser AM. The emerging role of echocardiography in the emergency department. Ann Emerg Med 1989;18(12):1298-303.

35. Jehle D, Davis E, Evans T, Harchelroad F, Martin M, Zaiser K, et al. Emergency department sonography by emergency physicians. Am J Emerg Med 1989;7(6):605-11.

36. Melanson SW, Heller M. The emerging role of bedside ultrasonography in trauma care. Emerg Med Clin North Am 1998;16 (1): $165-89$.

37. Abrams BJ, Wolfson AB. Bedside ultrasonography: the utility in emergency medicine. EM Rep 1996;17(15):151-60.

38. Heller M, Jehle D. Ultrasound in emergency medicine. Philadelphia: W.B. Saunders; 1995.

39. Simon BC, Snoey ER. Ultrasound in emergency and ambulatory medicine. St. Louis: Mosby-Year Book; 1997.

41. Blaivas M, Quinn J. Diagnosis of spontaneous splenic rupture with emergency ultrasonography. Ann Emerg Med 1998;32(5): 627-30.

40. Shackford SR, Rogers FB, Osler TM, Trabulsy ME, Clauss DW, Vane DW. Focused abdominal sonogram for trauma: the learning curve of nonradiologist clinicians in detecting hemoperitoneum. J Trauma 1999;46(4):553-62; discussion, 562-4.

42. Ma OJ, Mateer JR, Ogata M, Kefer MP, Wittmann D, Aprahamian C. Prospective analysis of a rapid trauma ultrasound examination performed by emergency physicians. J Trauma 1995; 38(6):879-85.

43. Shuman WP. CT of blunt abdominal trauma in adults. Radiology 1997;205(2):297-306.

44. Tiling T, Bouillon B, Schmid A. Ultrasound in blunt abdominothoracic trauma. In: Border AM Jr, Hansen ST, et al, editors. Blunt multiple trauma: comprehensive pathophysiology and care. New York: Marcel Dekker; 1990. p. 415-33.

45. Frager D. Intestinal obstruction role of CT. Gastroenterol Clin North Am 2002;31(3):777-99.

46. Frager D, Baer JW, Medwid SW, Rothpearl A, Bossart P. Detection of intestinal ischemia in patients with acute small-bowel obstruction due to adhesions or hernia: efficacy of CT. AJR Am J Roentgenol 1996;166(1):67-71.

47. Portis AJ, Sundaram CP. Diagnosis and initial management of kidney stones. Am Fam Physician 2001;63(7):1329-38.

48. Weyant MJ, Barie PS, Eachempati SR. Clinical role of noncontrast helical computed tomography in diagnosis of acute appendicitis. Am J Surg 2002;183(1):97-9.

49. Shen SH, Chen JD, Tiu CM, Chou YH, Chang CY, Yu C. Colonic diverticulitis diagnosed by computed tomography in the ED. Am J Emerg Med 2002;20(6):551-7.

50. Shams J, Stein A, Cooperman AM. Computed tomography for pancreatic diseases. Surg Clin North Am 2001;81(2):283-306.

51. Rubesin SE, Scotiniotis I, Birnbaum BA, Ginsberg GG. Radiologic and endoscopic diagnosis of Crohn's disease. Surg Clin North Am 2001;81(1):39-70, viii.

52. Levine MS, Kong V, Rubesin SE, Laufer I, Herlinger H. Scirrhous carcinoma of the stomach: radiologic and endoscopic diagnosis. Radiology 1990;175(1):151-4.

53. Greenwald DA, Brandt LJ, Reinus JF. Ischemic bowel disease in the elderly. Gastroenterol Clin North Am 2001;30(2):445-73.

Correspondence to: Dr. Glen Bandiera, Department of Emergency Services, St. Michael's Hospital, 30 Bond St., Toronto ON M5B 1W8; 416 864-5095, fax 416 864-5341, glen.bandiera@utoronto.ca

\section{ESAOTEPie Medical \\ THE IMAGE OF INNOVATION}

ESAOTE Pie Medical... providing highquality, yet affordable ultrasound scanners for over 25 years. From batterypowered portable units to sophisticated Doppler colour-flow systems, we offer exceptional value.
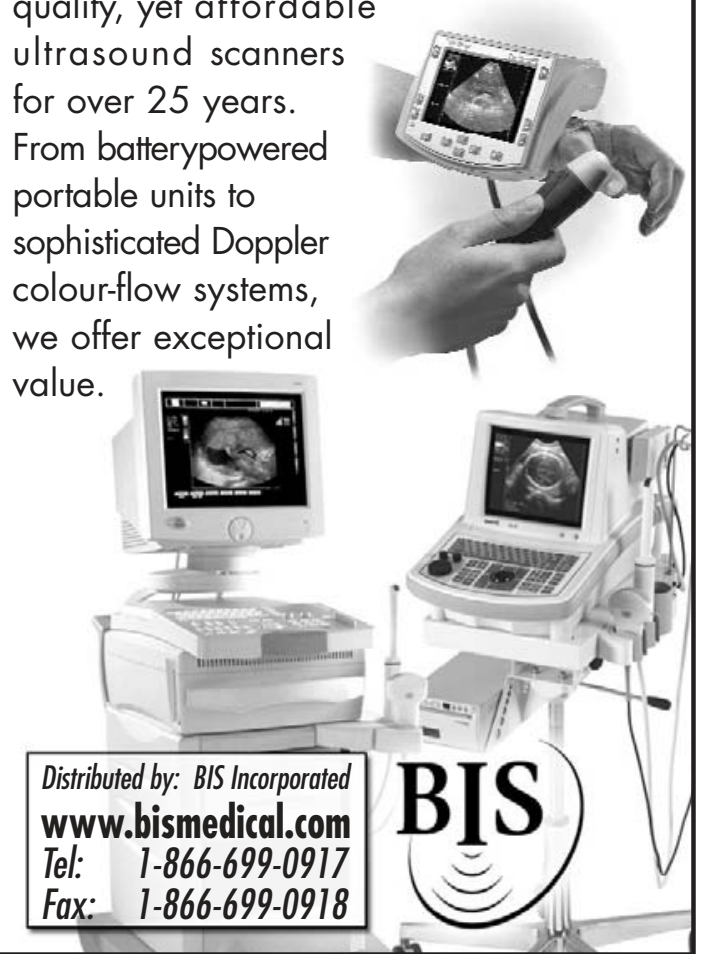